\title{
Utilization of Sprulina Algae to Improve the Nutritional Value of Kiwifruits and Cantaloupe Nectar Blends
}

\author{
Bahlol H.E.M. ${ }^{1}$; El-Desouky A.I. ${ }^{1}$; Sharoba A.M. ${ }^{1}$; Morsy O.M. ${ }^{2}$ and Abd El-Mawla, E.M. \\ 1 Food Technology Department, Faculty of Agriculture, Benha University, Egypt. \\ 2 Basic Sciences Department, Faculty of Engineering - Arab Academy for Science, Technology and Maritime \\ Transport, Egypt. \\ Corresponding author: hammam.bahlol@fagr.bu.edu.eg
}

\begin{abstract}
In this study use the spirulina which is one of the blue-green algae rich in protein $61.57 \%$ and contains a high proportion of essential amino acids (38.81\% of the protein) and a source of naturally rich in vitamins especially vitamin B complex such as vitamin B12 $(193 \mu \mathrm{g} / 100 \mathrm{~g})$ and folic acid $(9.66 \mathrm{mg} / 100 \mathrm{~g})$, which helps the growth and nutrition of the child brain, also rich in calcium and iron it containing (1043.625 and 338.765 $\mathrm{mg} / 100 \mathrm{~g}$, respectively) to protect against osteoporosis and blood diseases as well as a high percentage of natural fibers. So, the spirulina is useful and necessary for the growth of infants and very suitable for children, especially in the growth phase, the elderly and the visually appetite. It also, helps a lot in cases of general weakness, anemia and chronic constipation. Spirulina contain a selenium element $(0.0488 \mathrm{mg} / 100 \mathrm{~g})$ and many of the phytopigments such as chlorophyll and phycocyanin $(1.472 \%$ and $14.18 \%)$, and those seen as a powerful antioxidant. Finally, spirulina called the ideal food for mankind and the World Health Organization considered its "super food" and the best food for the future because of its nutritional value is very high. In this study, products supported with spirulina, kiwifruits and cantaloupe were manufactured. Two types of vegetable and fruit juices, green and were used frequently in commercial manufacturing (cantaloupe - kiwi). Spirulina was added to them at different ratios (zero "control samples", 2.5, 5, 7.5, 10, 12.5 and 15\%) The nectar blends were well studied to determine the best percentage of addition and the chemical, natural were done and sensory properties of nectar blends supported by spirulina. The all nectar blends prepared and supported by spirulina were highly accepted. Therefore, it is recommended to use spirulina in the field of strengthening juices, especially the rich types of chlorophyll, antioxidant and beneficial to public health such as kiwifruits and cantaloupe.
\end{abstract}

Key words: Spirulina - Kiwi Nectar - Cantaloupe Nectar - Chemical composition - Nutritional value - Sensory evaluation - Physiochemical characteristics.

\section{Introduction}

Spirulina (Arthrospira platensis) is a ubiquitous spiral-shaped blue-green microalgae, most commonly found in seawater and brackish water. Among the various species, $S$. platensis and $S$. maxima are the only two used as food. The blue-green color of the organism is due to the presence of various types of photosynthetic pigments like chlorophyll, carotenoids, phycocyanin and phycoerythrin. Phycocyanin is responsible for the blue color of the organism.

Spirulina is an alga containing a valuable combination of substances, including those practically absent in common food. Energetic value of $10 \mathrm{~g}$ dried Spirulina powder $-29 \mathrm{kcal}$ : fat $-0.7 \mathrm{~g}$, protein -5.7 $\mathrm{g}$, carbohydrate $-2.4 \mathrm{~g}$, vitamin A $-57 \mathrm{IU}$, vitamin B1 - $0.24 \mathrm{mg}$ (thiamine), B2 (riboflavin) $-0.38 \mathrm{mg}$, B3 (nicotinamide) $-1.3 \mathrm{mg}, \mathrm{B} 6$ (pyridoxine) $-0.4 \mathrm{mg}$, B9 (folic acid) - $9.4 \mathrm{mg}$, vitamin C $-1 \mathrm{mg}$, vitamin E $-0.5 \mathrm{mg}$, natrium - $104 \mathrm{mg}$, potassium - $136 \mathrm{mg}$, calcium $-12 \mathrm{mg}$, magnesium - $20 \mathrm{mg}$, iron $-2.8 \mathrm{mg}$, zinc - $0.2 \mathrm{mg}$ Peciukoniene et al. (2001).

Spirulina fusiformis, a blue-green algae, (Oscillotoreaceae) is rich in proteins, lipids and carbohydrates, as well as elements such as zinc, magnesium, manganese, selenium, and some vitamins including $\beta$-carotene, riboflavin, cyanocobalamin, $\alpha$ - tocopherol and $\alpha$-lipoicacid. Spirulinais also reputed to be an external source of the vital antioxidant enzyme superoxide dismutase (Upasani and Balaraman, 2003).

Chemical analysis of Spirulina showed that it is an excellent source of proteins, vitamins, dietary minerals and pigments. The biochemical composition depends upon the specific Arthrospira source, culture conditions and season of production Habib et al. (2008); Henrikson (2009) and Falquet (2012).

The nutrient content of spirulina was analyzed by Vijayarani et al. (2012) and it contains $6.47 \mathrm{~g}$ of moisture, $0.17 \mathrm{~g}$ of ash, $347.96 \mathrm{~g}$ of energy, $62.4 \mathrm{~g}$ of protein, $1.07 \mathrm{~g}$ of fat, $22.24 \mathrm{~g}$ of carbohydrates, 90.48 $\mathrm{mg}$ of iron, $825.1 \mathrm{mg}$ of calcium, $744.39 \mathrm{mg}$ of phosphorous and $3495 \mu \mathrm{g}$ of carotene.

Spirulina has found wide applications in the areas of agriculture, food, pharmaceuticals, perfumeries, medicine and science. Nowadays, this organism is used as a food supplement and is marketed in the form of pills, capsules and powder or incorporated into various types of food like cakes, biscuits, noodles and health drinks, etc. Desai and Sivakami (2004).

As functional food, additive and prebiotic: Spirulina has earned scientific validation regarding its role as healthy food component. This nutritious and easily digestible food can be consumed in several forms. It was demonstrated that the whole spirulina or 
its phycocyanin-rich fraction could be a suitable functional ingredient in soy milk, fruit juices and whole fruits (McCarty (2007). It was suggested that the ingestion of cocoa and spirulina powder mix can promote antioxidant status and vascular health (McCarty et al. (2010). Spirulina is expected to enhance the nutritional content of conventional foods when incorporated as colorant, texturizing agent, gelling agent and prebiotic. The pigments phycocyanin and allophycocyanin are used in the food and beverage industry as a natural colorant. This blue colorant finds use in ice cream, sweets, chewing gum, candy, jelly, cake decorations as well as soft drinks, alcoholic drinks (Liu et al. (2012).

At present, there are two categories of spirulina food. The first is the pills and capsules made from dry spirulina. Food containing spirulina and other ingredients belongs to the other category. Examples are instant noodles, stylish noodles, nutritious blocks, beverages and cookies. The first three food items are recommended luncheon food for middle grade school students by the State Commission of Education Committee (Li Ding-Mei and Qi Yu-Zao, 1997).

The aims of the present work study the chemical, physical, nutrition of characteristics of spirulina, and produce some juices and nectar some juices and nectar blends blends with spirulina.

\section{Materials and Methods}

\section{Materials:}

The raw materials used throughout this study for producing and evaluation of spirulina products were:

1.1. Spirulina: Spirulina was obtained from Aquaculture Research Center at Arab Academy for Science, Technology and Maritime Transport, Arab League.

1.2. Cantaloupe (Cucumir melon) fruits were picked at the ripe stage from a certain farm in Ismailia Governorate, Egypt.

1.3. Kiwifruit fruits (Spanish name): kiwifruit or kiwi, Family: Actinidiaceae, Genus: Actinidia, Species: A. Deliciosa. Kiwifruit fruits are obtained from local markets in Egypt. The fruits, weighing between 120 to $125 \mathrm{~g}$.

1.4. The starting materials used in preparation of spirulina juices, i.e. sugar, citric acid and sodium bonzaote were obtained from local markets in Quliobia Governorate, Egypt.

\section{Preparation and processing:}

2.1. Spirulina preparation: Spirulina was cultivated, harvested and dried at Aquaculture Research Center at Arab Academy for Science, Technology \& Maritime Transport, Arab League, Then were obtained spirulina dryer, floured and soft and ready for use.

2.2. Cantaloupe: ripe cantaloupe fruits were washed with running water, hand peeled, the seeds were removed, and the flesh was diced. The juices were mechanically extracted by using Moulinex blender (Blender Mixer, type: 741). The puree was strained by 0.023 inch screen to remove stone cells, to avoid coarse pulp particles and to have only fine particles of almost colloidal consistency.

2.3. Kiwifruits: Kiwifruits were supplied by a local producer, fruits were washed, dried in air, hand peeled, seeds carefully removed and cut into small parts. The Kiwifruits puree was extracted by Moulinex blender (Blender Mixer, type: 741). It took five minutes blending to get Kiwifruits puree. The puree was strained by a stainless steel strainer, then strained again by a clean muslin cloth to get rid of seeds and peels for obtaining Kiwifruits puree.

Cantaloupe juice and Kiwifruits purees were divided into two parts:

- The first part was used to determine the chemical composition and sensory evaluation.

- The second part was used in preparation of different nectars blends with dried spirulina powder after that these blends were used for all analysis.

2.4. Cantaloupe nectar: nectar was prepared from the $25 \%$ cantaloupe puree to get: total soluble solids $17 \%$ and $\mathrm{pH} 3.5$, according to the method described by ElMansy et al. (2005) and Sharoba et al. (2007 and 2012).

2.5. Kiwifruits nectar: nectar was prepared from the $25 \%$ Kiwifruits puree to get: total soluble solids $17 \%$ and $\mathrm{pH} 3.5$, according to the method described by ElMansy et al. (2005) and Sharoba et al. (2007 and 2012).

2.6. Cantaloupe and Kiwi fruits nectar blends: the cantaloupe and Kiwi fruits purees were blended together as follows in Table (A). Each blend was added by $25 \%$ to water, sugar and citric acid to production the nectars, and adjusting $\mathrm{pH}$ to 3.5 is done conveniently by adding citric acid as $50 \%$ (w/v) solution according to El-Mansy et al. (2005) and Sharoba et al. (2007 and 2012).

Table A. Percentage of ingredients used to preapration of cantaloupe and kiwi fruits nectar blends.

\begin{tabular}{|c|c|c|c|c|c|}
\hline \multirow[b]{2}{*}{$\begin{array}{c}\text { Blends } \\
\text { No. }\end{array}$} & \multicolumn{2}{|c|}{ Cantaloupe blends } & \multirow[b]{2}{*}{$\begin{array}{l}\text { Blends } \\
\text { No. }\end{array}$} & \multicolumn{2}{|c|}{ Kiwi fruits blends } \\
\hline & $\begin{array}{c}\text { Cantaloupe puree } \\
(\%)\end{array}$ & $\begin{array}{c}\text { Dried spirulina } \\
\text { powder }(\%)\end{array}$ & & $\begin{array}{c}\text { Kiwi fruits puree } \\
(\%)\end{array}$ & $\begin{array}{c}\text { Dried spirulina } \\
\text { powder }(\%)\end{array}$ \\
\hline CN1 & 100 & - & KN1 & 100 & - \\
\hline CN 2 & 95 & 5 & KN 2 & 95 & 5 \\
\hline CN 3 & 90 & 10 & KN 3 & 90 & 10 \\
\hline $\mathrm{CN} 4$ & 85 & 15 & KN 4 & 85 & 15 \\
\hline CN 5 & 80 & 20 & KN 5 & 80 & 20 \\
\hline
\end{tabular}

$\mathrm{CN}$ : Cantaloupe nectar.

KN: Kiwi fruits nectar. 
2. Method of analysis:

2.1. Proximate analysis:

Moisture, crude protein, crude fat, total dietary fibre and ash were determined using the appropriate A.O.A.C. (2005). Carbohydrates were determined by difference.

2.2. Total soluble solids:

The total soluble solids content were determined using a Abbe refrectometer Model 1T

AT $20^{\circ} \mathrm{C}$ according to A.O.A.C. (2005).

\section{3. $\mathrm{pH}$ values:}

The $\mathrm{pH}$ values were measured by using a $\mathrm{pH}$ meter Model Consort $\mathrm{pH}$ meter P107.

\subsection{Titratable acidity:}

Twenty grams of juice, pulp nectar blends samples were mixed with $150 \mathrm{ml}$ of distilled water. The resulting mixture was titrated with $0.1 \mathrm{~N} \mathrm{NaOH}$ solution to $\mathrm{pH} 6$ using a Consort $\mathrm{pH}$ meter P107. Results were reported as percent citric acid.

\subsection{Ascorbic acid determination:}

Ascorbic acid determination using the 2,6dichlorophenol indophenol dye by titration method of A.O.A.C. (2005).

\subsection{Total and reducing sugars:}

Total and reducing sugars were determined by Shaffer and Hartman method as described in A.O.A.C. (2005) while nonreducing sugars were calculated by difference.

\subsection{Total pectic substances:}

Total pectic substances contents were determined by the method of Carre and Hayness, which was described by Person (1976).

2.8. Determination of chlorophyll and carotenoids:

Fresh samples of red pepper fruit or tomato were homogenized using a pestle and mortar in the presence of water bath contains squash ice. Sixteen milliliters of acetone-hexane (4:6) solvent were added to $1.0 \mathrm{~g}$ of homogenated sample and mixed in a testtube. Automatically, two phases were separated, and an aliquot was taken from the upper solution to measure its optical density (OD) at 663, 645, 505, and $453 \mathrm{~nm}$ in a spectropho-tometer. Chlorophyll a, b and $\beta$-carotene contents were calculated according to Nagata and Yamashita (1992) equations:
Chlorophyll a $(\mathrm{mg} / 100 \mathrm{ml}$ of extract $)=(0.999 \times$ OD 663) - (0.0989 x OD 645)

Chlorophyll $\mathrm{b}(\mathrm{mg} / 100 \mathrm{ml}$ of extract $)=(-0.328 \times$ OD $663)+(1.77$ X OD 645)

$\beta$-Carotene $(\mathrm{mg} / 100 \mathrm{ml}$ of extract $)=(0.216 \times$ OD 663 - 1.22 x OD $645-0.304$ x OD $505+0.452$ x OD 453). Chlorophyll a, b and $\beta$-Carotene were finally expressed as $\mathrm{mg} / 100 \mathrm{ml}$.

\section{Sensory evaluation:}

Sensory evaluation was carried out by a properly well trained panel of twenty adults testers. They were selected if their individual scores in 10 different tests showed a reproducibility of $90 \%$. The 12 members internal panel evaluated the different juices for texture or mouthfeel (smoothness, consistency, and spreadability), color, taste, odor and overall acceptability. Mineral water was used by the panellists to rinse the mouth between samples. Scoring was based on a 100 point scale (10-100) where $(90-100)=$ excellent, $(70-80)=$ very good, $(50-$ $60)=$ good, $(30-40)=$ fair and $(10-20)=$ poor, according to Onweluzo et al. (1999) and Sharoba et al. (2007).

\section{Statistical analysis:}

Statistical analysis was carried out using Complete Randomized Design (CRD) giving analysis of variance (AVOVA) for significance at $5 \%$ of each treatment. Data of chemical composition of ingredients and blends were expressed as mean of three replicates + standard error (SE). Data for the sensory evaluation of all nectar blends were subjected to the analysis of variance followed by multiple comparison using LSD $(\mathrm{P}<0.05)$ (Snedecor and Cochran, 1989).

\section{Results and Discussion}

\section{Proximate chemical composition of raw materials:}

Spirulina analyzed for moisture, total solids, ash, fat, protein, $\mathrm{pH}$ values, fiber, starch, total carbohydrates, amino acids, vitamins and phytopigments and minerals. Results recorded in Tables (1-5) show some chemical and physical properties of starting spirulina material which was used in this study.

Table 1. Chemical composition of spirulina (g/100 g sample).

\begin{tabular}{lc}
\hline \multicolumn{1}{c}{ Components } & Values*\% \\
\hline Moisture & $5.37 \pm 0.24$ \\
\hline Total solids & $\mathbf{9 4 . 6 3}$ \\
\hline Protein* & $61.57 \pm 1.61$ \\
\hline Crude fat* & $7.19 \pm 0.25$ \\
\hline Ash content* & $7.10 \pm 0.09$ \\
\hline Fiber* & $7.93 \pm 0.38$ \\
\hline Available carbohydrates*\# & 16.21 \\
\hline * (on dry weight basis) & \\
\#: Available carbohydrate by difference &
\end{tabular}


The chemical and nutritional composition of dried powdered spirulina grown in fresh water is summarized in Tables (1). It should be noted that, the cell wall of spirulina is composed of protein, carbohydrates and fat. Therefore, the bioavailability of nutrients from spirulina might be more than from other food sources, especially plant food sources.

Spirulina is the richest nutrient and complete food source found in the world. It contains over 100 nutrients, more than any other plants, grains or herbs. Today spirulina is widely used as a food supplement to maintain health, boost energy and reduce weight. Spirulina contains $61.57 \%$ protein, higher than any other natural food. Spirulina contains all the essential amino acids in fairly high amounts, spirulina is just that, a complete protein, other protein sources have very negative properties as well, such as animal fat and cholesterol. Spirulina contains essence minerals like calcium, magnesium, potassium, phosphorus, iron, and zinc as well as complete vitamin B groups and many important anti-oxidants (which protect cells). The anti-oxidant phycocyanin can only be found in spirulina. It is the richest natural source of vitamin $\mathrm{E}$ and beta-carotene. The results of chemical composition of spirulina are in agreement with those obtained by Branger et al. (2003); Habib et al. (2008); Vijayarani et al. (2012) and Dolly (2014).

Spirulina's fat content is only $7.19 \%$, far lower than almost all other protein sources.

Table 2. Amino acids content of spirulina (mg/100 g).

\begin{tabular}{lllc}
\hline Essential amino acids & Values & Non-essential amino acids & Values \\
\hline Isoleucine & $\mathbf{6 . 7 8}$ & Alanine & 7.36 \\
\hline Leucine & 7.67 & Arginine & 7.65 \\
\hline Lysine & 4.37 & Aspartic & 11.17 \\
\hline Methionine & 2.39 & Cysteine & 1.28 \\
\hline Phenylalanine & 4.42 & Glutamic & 13.79 \\
\hline Threonine & 4.88 & Glycine & 5.24 \\
\hline Tryptophan & 1.93 & Histidine & 2.71 \\
\hline Valine & 6.37 & Proline & 4.35 \\
\hline & Serine & 4.16 \\
\hline & & Tyrosin & 3.48 \\
\hline Total EAA & 38.81 & Total NEAA & 61.19 \\
\hline \% Protein & & 61.57 & \\
\hline
\end{tabular}

Vitamin B-12 and B-complex vitamins: Spirulina is the richest source of B-12, higher than beef liver, chlorella or sea vegetables. B-12 is necessary for development of red blood cells, especially in the bone marrow and nervous system. Although primary B-12 deficiencies, pernicious anemia and nerve degeneration, are quite rare, because B-12 is the most difficult vitamin to get from plant sources, vegetarians have taken to spirulina. Ten grams contain $1930 \mu \mathrm{g}$ of Vitamin B-12.

One gram provides significant quantities of thiamin $(5.61 \mathrm{mg})$, riboflavin $(4.94 \mathrm{mg})$ and niacin (17.19 mg). Spirulina is a richer source of these vitamins than common whole grains, fruits and vegetables and some seeds. Other B vitamins, B-6, niacin, biotin, panthothenic acid, folic acid, inositol and Vitamin $\mathrm{E}$ are also present in smaller amounts.

Table 3. Vitamins and phytopigments in spirulina*.

\begin{tabular}{|c|c|c|c|}
\hline Vitamins & Value & Phytopigments & $(\%)$ \\
\hline Vitamin B1(Thiamine) & $5.61 \mathrm{mg}$ & Total Carotenoids & 0.551 \\
\hline Vitamin B2 (Riboflavin) & $4.94 \mathrm{mg}$ & Beta carotenoids & 0.243 \\
\hline Vitamin B3 (Niacin) & $17.19 \mathrm{mg}$ & Xanthophylls & 0.271 \\
\hline Vitamin B6 (Pyridoxine) & $0.87 \mathrm{mg}$ & Zeaxanthin & 0.128 \\
\hline Vitamin B12 (Analogue) & $193 \mu \mathrm{g}$ & Chlorophyll & 1.472 \\
\hline Folic acid & $9.66 \mathrm{mg}$ & Phycocyanin & 14.18 \\
\hline Inositol & $58.39 \mathrm{mg}$ & & \\
\hline Vitamin E & $9.57 \mathrm{mg}$ & & \\
\hline Vitamin K & $1124 \mu \mathrm{g}$ & & \\
\hline Pantothenate & $136 \mu \mathrm{g}$ & & \\
\hline Biotin & $8.32 \mu \mathrm{g}$ & & \\
\hline
\end{tabular}

Calcium, magnesium, zinc and trace minerals. Spirulina is a concentrated calcium food, supplying more, gram for gram, than milk. Ten grams supply $104.3 \mathrm{mg}$ of calcium. Ten grams supply $0.14 \mathrm{mg}$ of 
magnesium, one of the most concentrated magnesium foods. Magnesium facilitates absorption of calcium and helps regulate blood pressure. While, spirulina is low in sodium. Humans need dozens of essential trace minerals for the functioning of enzyme systems and many other physiological functions. Deficiency of trace minerals in the typical diet are thought to be widespread. Ten grams supply manganese $(0.7 \mathrm{mg})$, chromium (0.04 mg), selenium (0.005 mg), copper $(0.15 \mathrm{mg})$ and zinc $(0.44 \mathrm{mg})$.

Table 4. Minerals content in spirulina (mg/100 g).

\begin{tabular}{llll}
\hline Macro-elements & Value & Micro-elements & Value \\
\hline $\mathrm{Ca}$ & $\mathbf{1 0 4 3 . 6 2 5}$ & $\mathrm{Cu}$ & $\mathbf{1 . 5 0 7 1}$ \\
\hline $\mathrm{K}$ & $\mathbf{2 1 8 5 . 7 4 4}$ & Fe & $\mathbf{3 3 8 . 7 6 5}$ \\
\hline $\mathrm{Mg}$ & $\mathbf{1 . 4 7 5 9}$ & $\mathrm{Mn}$ & $\mathbf{7 . 0 1 9 4}$ \\
\hline $\mathrm{Na}$ & $\mathbf{1 5 1 0 . 1 6 8}$ & $\mathrm{Zn}$ & $\mathbf{4 . 4 9 2 4}$ \\
\hline $\mathrm{P}$ & $\mathbf{1 9 1 7 . 7 1 8}$ & $\mathrm{Cr}$ & $\mathbf{0 . 4 0 3}$ \\
\hline & & $\mathrm{Se}$ & $\mathbf{0 . 0 4 8 8}$ \\
\hline & $\mathrm{B}$ & $\mathbf{3 . 5 6 5}$ \\
\hline & $\mathrm{Mo}$ & $\mathbf{0 . 4 6 1 3}$ \\
\hline
\end{tabular}

* Value represents average of three determinations

\section{Physicochemical properties of kiwifruits juice and cantaloupe puree: \\ The results of the physico-chemical} characterization of kiwifruits juice and cantaloupe puree are shown in Table (5). The values obtained for purees are similar to those reported elsewhere (Cassano et al., (2007). Numerous reports on the chemical composition of kiwifruits juice and cantaloupe puree have appeared in the literature but refer to old cultivars which are used less and less by industry. Hence, there is a need to characterize new varieties of kiwifruits juice and cantaloupe puree, which have been utilized by the food industry for some years. These results of kiwifruits juice and cantaloupe puree are in agreement with those obtained by Connie et al., (2006), Cassano et al. (2007) and Jurmkwan et al. (2008)

Data recorded in Table (5) show the chemical properties of fruits puree. The solids content is an important factor in the production of nectar. It is well known that the higher the total solids the better will be the quality of the end product. From the tabulated data it is clear that the moisture content in the prepared fruits puree was ranged from $88.76 \%$ in kiwifruits juice to $89.84 \%$ in cantaloupe puree, while the total solids were ranged from $11.24 \%$ for kiwifruits juice to $10.16 \%$ for cantaloupe puree. Results appeared that cantaloupe puree has low percent of ash content $0.485 \%$, while kiwifruits juice had the high percentage of ash content $0.645 \%$. The highest percent of ash in this fruits puree encourage to use these fruits as the main component in the preparation of nectar. Also, these fruits had high values of total soiled. Moreover kiwifruits juice and cantaloupe puree were found in the market at most time in the year in contrast with some other vegetables and fruits, behind the price of cantaloupe fruits were suitable for all family in Egypt.

Regarding for fat content in the results, data indicated that each of fruits has less than $1 \%$. Also the same results for protein levels were less than $1 \%$. Carbohydrates are considered as one of the most important quality parameters for fruits and the contributing influence of palatability, quality and formation of discoloration, process ability and viscosity. It was estimated as total sugars, reducing sugar, non reducing sugars and pectic substances. Values of these data are tabulated in the Table (5). The highest percentage of sugars was found in kiwifruits juice, followed by cantaloupe puree.

Pectic substances are the main factor which greatly influences the quality, stability, process ability and viscosity of prepared fruits nectars. The total pectic content of fruits was the sum of the pectin fractions extract; water extract, ammonium oxalate extract and acid extract. Total pectic substances were ranged from $1.56 \%$ in kiwifruits juice and $1.25 \%$ in cantaloupe puree. The pectin can hold the water in stomach. So, pectin is very important for sportiest and children especially when thy have diarrhea. On the other hand, cantaloupe puree had the higher level of fiber $(0.68 \%)$ followed by kiwifruits juice $(0.65 \%)$.

The titratable acidity and $\mathrm{pH}$ values are considered as important factor correlated to the quality and flavor of fruits. As shown in the Table (5) the $\mathrm{pH}$ values were 5.26 for kiwifruits juice and 6.45 in cantaloupe puree, the important of $\mathrm{pH}$ values when the food was treated by heat to preserve it.

As known that carotenoids and chlorophyll help the peoples as color to attract any food. Also, epidemiological studies have shown that increased consumption of fruits is associated with reduced risk of lung and other epithelial cancers. It has been suggested that high carotenoid levels in fruits are responsible for this reduced risk.

Fruits products are considered as a good source of vit. C. The results obtained in Table (5) showed that all fruits under investigation contained the good percent of vit. C.

Nutritional value was estimated by determining the gross chemical composition, as well as the foods sensory characteristics of different samples were also evaluated. The results of chemical composition and physical properties for ingredients 
used for the preparation of fruits nectar formulas were in agreement with those obtained by Connie $\boldsymbol{e t}$ al.
(2006) Cassano et al. (2007) and Jurmkwan et al. (2008).

Table 5. Physicochemical properties of kiwi fruits juice and cantaloupe puree*.

\begin{tabular}{|c|c|c|}
\hline \multirow{2}{*}{ Components } & \multicolumn{2}{|c|}{ Mean values } \\
\hline & Kiwi fruits juice & Cantaloupe puree \\
\hline Moisture \% & $88.76 \pm 1.26$ & $89.84 \pm 1.49$ \\
\hline Total solids \% & 11.24 & 10.16 \\
\hline Ash \% & $0.645 \pm 0.004$ & $0.485 \pm 0.006$ \\
\hline Titratable acidity \% (as citric acid) & $0.189 \pm 0.001$ & $0.127 \pm 0.001$ \\
\hline pH value & $5.26 \pm 0.02$ & $6.45 \pm 0.03$ \\
\hline Ascorbic acid (mg/100 ml) & $52.68 \pm 1.78$ & $45.24 \pm 2.07$ \\
\hline Protein \% & $0.986 \pm 0.002$ & $0.965 \pm 0.003$ \\
\hline Fat \% & $0.327 \pm 0.004$ & $0.265 \pm 0.003$ \\
\hline Fibre \% & $0.658 \pm 0.003$ & $0.689 \pm 0.002$ \\
\hline Total sugars \% & $6.734 \pm 0.024$ & $6.307 \pm 0.035$ \\
\hline Reducing sugars \% & $4.801 \pm 0.017$ & $4.675 \pm 0.019$ \\
\hline Non-reducing sugars \% & 1.933 & 1.632 \\
\hline Total pectic substances $\%$ & $1.561 \pm 0.007$ & $1.246 \pm 0.009$ \\
\hline Carotenoids (mg/L) & $3.96 \pm 0.002$ & $4.68 \pm 0.006$ \\
\hline Chlorophyll (mg/L) & $17.78 \pm 0.021$ & $14.92 \pm 0.013$ \\
\hline
\end{tabular}

Some physical and chemical characteristics of cantaloupe and Kiwi fruits nectar blended with spirulina by different percent:

Moisture, crude protein, fat, crude fiber, ash, sugar, pectin and vit. $\mathrm{C}$ which were thought to be great importance in the characterizes where determined.

The fruits nectar enhancement by spirulina (as a source of protein) formulas were prepared to produce as complementary beverages for classes for all human beings who need to increase the protein in their food such as sportsmen's, infants, children, pregnant and lactating women and patients. Prepared fruits nectars were make by using cantaloupe and kiwi fruits fruits. The visibility of chemical composition is too important. Data in Table (6) indicated that moisture and total solids content in prepared fruits nectar blends nearly varied. This is due to the adding different rate of spirulina. Control sample of cantaloupe and kiwi fruits nectars had the lowest level of ash content followed by other blends. Fat in all formulas was ranged between $1 \%$. The protein content of blends was ranged from 0.331 to $8.763 \%$, especially the nectars content $10 \%$ spirulina. These results are in agreement with trend showed by Osman (2012) who added soy bean products (as a source of protein) for fruits nectar. Titratable acidity and $\mathrm{pH}$ values are important as it affected on the taste and flavor. The $\mathrm{pH}$ values indicated that all formulas were acid food. The obtained data indicated that the total sugars were the major component in total solids in all blends and the main source of energy value. The percentages of total pectic substances and fiber content were acceptable and suitable for sportsmen's, infants, children, pregnant \& lactating women and patients related to the importance of those for absorptive of water in bodies and excretion. Pectin is very important for children related to hung the water in stomach especially if the children have diarrhea. More over pectin improve the texture of nectar, so the all consumers' can be accepted these nectars.

The level of chlorophyll and carotenoids in cantaloupe and kiwi fruits nectars formulas which contained spirulina was higher than control formulas. Also, data indicated that ascorbic acid in all cantaloupe and kiwi fruits nectars formulas was ranged from 12.2 to $16.38 \mathrm{mg} / 100 \mathrm{~g}$ in all formulas. Energy values for formulate prepared fruits nectar formulas were estimated from the percentage of total carbohydrates, protein and fat contents, the values were ranged between 64.15 and $67.16 \mathrm{cal} / 100 \mathrm{~g}$ nectar formula. These results for the prepared fruits nectar formulas were in agreement with those obtained by Sharoba (1999), Bahlol et al. (2007) and El-Mansy et al. (2005). Also, the results within the limiting of all Egyptian standards for juices and beverages.

Finally, it could be clear that the prepared fruits nectar blends is covered the daily requirements according to FAO (2004), of fiber, sugar, pectin, calories, carotenoids and vit. C, so it suitable for sportsmen's and babies specially babies suffering from some sub-clinical dieses like (caloric deficiency, dehydration, diarrhea, normal laxation, night blindness and scurvy), also this results noted that. It may be used in dietetic food and by diabetes patients. Finally, suitable for all peoples in all ages. The chlorophyll and carotenoids contents in any fruits nectar enhancement by spirulina formulas. Eating 100 $\mathrm{g}$ from any prepared fruits nectar blendes will covered the daily requirements of fiber and carotenoids. It had a high value of vitamin $\mathrm{C}$ content. This blend will cover the daily requirements of vitamin $\mathrm{C}$. 
Table 6. Some physical and chemical characteristics of cantaloupe and kiwi fruits nectar blended with spirulina by different percent.

\begin{tabular}{|c|c|c|c|c|c|c|}
\hline \multirow[t]{2}{*}{ Parameters } & \multirow{2}{*}{$\begin{array}{c}\text { Cantaloupe } \\
\text { nectar } \\
\text { (control) } \\
\end{array}$} & \multicolumn{2}{|c|}{$\begin{array}{c}\text { Cantaloupe nectar blended } \\
\text { with spirulina }\end{array}$} & \multirow{2}{*}{$\begin{array}{l}\text { Kiwi fruits } \\
\text { nectar } \\
\text { (control) }\end{array}$} & \multicolumn{2}{|c|}{$\begin{array}{l}\text { Kiwi fruits nectar blended } \\
\text { with spirulina }\end{array}$} \\
\hline & & $5 \%$ & $10 \%$ & & $5 \%$ & $10 \%$ \\
\hline Moisture (\%) & $82.71 \pm 1.32$ & $82.47 \pm 0.95$ & $82.52 \pm 0.94$ & $82.63 \pm 1.34$ & 82.71 \pm 1.07 & $82.65 \pm 1.30$ \\
\hline Total solids & 17.29 & 17.53 & 17.48 & 17.37 & 17.29 & 17.35 \\
\hline Crude protein $(\%)$ & $0.331 \pm 0.003$ & $4.361 \pm 0.001$ & $8.763 \pm 0.001$ & $0.327 \pm 0.002$ & $4.357 \pm 0.001$ & $8.759 \pm 0.27$ \\
\hline Crude fat $(\%)$ & $0.132 \pm 0.001$ & $0.652 \pm 0.001$ & $1.226 \pm 0.007$ & $0.117 \pm 0.004$ & $0.638 \pm 0.001$ & $1.198 \pm 0.031$ \\
\hline Crude fiber (\%) & $0.208 \pm 0.002$ & $0.728 \pm 0.008$ & $1.296 \pm 0.001$ & $0.214 \pm 0.003$ & $0.734 \pm 0.008$ & $1.302 \pm 0.011$ \\
\hline $\operatorname{Ash}(\%)$ & $0.206 \pm 0.002$ & $0.694 \pm 0.004$ & $1.226 \pm 0.007$ & $0.241 \pm 0.004$ & $0.7285 \pm 0.001$ & $1.261 \pm 0.002$ \\
\hline $\begin{array}{l}\text { Titratable acidity } \\
(\%)\end{array}$ & $0.251 \pm 0.001$ & $0.246 \pm 0.002$ & $0.231 \pm 0.004$ & $0.245 \pm 0.001$ & $0.245 \pm 0.004$ & $0.245 \pm 0.001$ \\
\hline pH values & $3.50 \pm 0.03$ & $3.51 \pm 0.01$ & $3.51 \pm 0.01$ & $3.50 \pm 0.02$ & $3.50 \pm 0.01$ & $3.51 \pm 0.01$ \\
\hline Total sugars (\%) & $6.307 \pm 0.015$ & $10.42 \pm 0.317$ & $4.32 \pm 0.34$ & $6.734 \pm 0.012$ & $10.13 \pm 0.224$ & $4.12 \pm 0.187$ \\
\hline Total pectin (\%) & $0.438 \pm 0.008$ & $0.428 \pm 0.014$ & $0.422 \pm 0.120$ & $0.465 \pm 0.004$ & $0.465 \pm 0.011$ & $0.465 \pm 0.008$ \\
\hline $\begin{array}{l}\text { Vitamin C (mg } \\
\text { /100g) }\end{array}$ & $13.41 \pm 1.23$ & $12.58 \pm 0.027$ & $12.2 \pm 0.088$ & $16.38 \pm 0.85$ & $16.16 \pm 0.172$ & $16.08 \pm 1.04$ \\
\hline Carotenoids (mg/l) & $1.63 \pm 0.002$ & $32.41 \pm 1.82$ & $54.11 \pm 2.07$ & $1.28 \pm 0.001$ & $29.18 \pm 1.47$ & $47.33 \pm 2.18$ \\
\hline Chlorophyll (mg/l) & $5.96 \pm 0.017$ & $82.47 \pm 2.47$ & $122.31 \pm 3.82$ & $6.27 \pm 0.024$ & $89.21 \pm 3.11$ & $118.04 \pm 2.98$ \\
\hline $\begin{array}{l}\text { Energy values } \\
\text { (Kcal.) }\end{array}$ & 67.16 & 66.71 & 65.008 & 67.16 & 65.48 & 64.158 \\
\hline
\end{tabular}

Effect of adding spirulina on sensory properties of cantaloupe nectar and kiwifruits nectar blends:

Sensory evaluation is generally the final guide of the quality from the consumer's point of view. Thus, it is beneficial to make a comparison between the nectars blends, which were applied. Organoleptic parameters, indicate the possibility of nectar for acceptability. Blending of fruit nectars could be an economic requisite and also needed to improve the appearance, nutrition and flavor. Texture (Mouthfeel), color, taste, odor and overall acceptability of different Kiwi fruits and cantaloupe nectars blends were organoleptically evaluated, the results are here often in Tables (7 and 8). Significant differences among the all tested nectars. Regarding the texture of Kiwi fruits and cantaloupe nectars, results in Table (7) reflect that the texture of nectars (10\% spirulina) and $(12.5 \%$ spirulina) had the highest scores compared with the other nectars. There are significant differences among the tested nectars. Regarding the mouthfeel (texture) of kiwi fruits and cantaloupe nectars, results in Tables (7 and 8) reflect that the mouthfeel of nectars $(7.5 \%$ spirulina) and (10\% spirulina) had the highest scores compared with the other blends. In the same time the two blends have the higher scores in all other attributes. The lower scores in all attributes were for nectars (17.5 and 20\% spirulina, respectively), the results of sensory tests were in agreement with Fradique et al. (2010) and Liu et al. (2012) they were observed that the incorporation of spirulina increases food texture and imparts it a stable color. Sensory analysis also showed better acceptance scores.

Table 7. Sensory properties of spirulina and kiwifruits nectar blends (mean \pm S.E.).

\begin{tabular}{|c|c|c|c|c|c|}
\hline \multirow[b]{2}{*}{ Nectar blends } & \multicolumn{5}{|c|}{ Sensory attributes } \\
\hline & $\begin{array}{c}\text { Texture } \\
\text { (Mouthfeel) } \\
(25) \\
\end{array}$ & $\begin{array}{c}\text { Color } \\
\text { (25) }\end{array}$ & $\begin{array}{c}\text { Taste } \\
(25)\end{array}$ & $\begin{array}{l}\text { Odor } \\
(25)\end{array}$ & $\begin{array}{c}\text { Overall } \\
\text { acceptability } \\
(\mathbf{1 0 0}) \\
\end{array}$ \\
\hline Kiwifruits nectar & $18.58 \pm 0.34^{f}$ & $19.50 \pm 0.50^{d}$ & $19.17 \pm 0.32^{d}$ & $17.50 \pm 0.48^{\text {fg }}$ & $83.58 \pm 0.45^{\mathrm{e}}$ \\
\hline $\mathrm{KP}+2.5 \% \mathrm{SP}$ & $19.58 \pm 0.26^{\mathrm{e}}$ & $22.25 \pm 0.35^{\mathrm{c}}$ & $20.50 \pm 0.45^{b c}$ & $18.67 \pm 0.43^{e}$ & $86.42 \pm 0.66^{d}$ \\
\hline $\mathrm{KP}+5 \% \mathrm{SP}$ & $21.25 \pm 0.35^{d}$ & $22.83 \pm 0.34^{\text {bc }}$ & $21.25 \pm 0.25^{b}$ & $20.08 \pm 0.40^{\mathrm{cd}}$ & $89.17 \pm 0.69^{c}$ \\
\hline $\mathrm{KP}+7.5 \% \mathrm{SP}$ & $22.25 \pm 0.30^{c}$ & $23.67 \pm 0.22^{a b}$ & $22.17 \pm 0.30^{a}$ & $21.50 \pm 0.29^{b}$ & $92.67 \pm 0.50^{b}$ \\
\hline $\mathrm{KP}+10 \% \mathrm{SP}$ & $22.67 \pm 0.43^{\text {bc }}$ & $24.25 \pm 0.21^{\mathrm{a}}$ & $22.67 \pm 0.28^{a}$ & $22.50 \pm 0.31^{\mathrm{a}}$ & $94.25 \pm 0.28^{a}$ \\
\hline $\mathrm{KP}+12.5 \% \mathrm{SP}$ & $23.75 \pm 0.25^{a}$ & $20.58 \pm 0.54^{d}$ & $19.91 \pm 0.31^{\mathrm{cd}}$ & $19.67 \pm 0.31^{d}$ & $87.17 \pm 0.56^{d}$ \\
\hline $\mathrm{KP}+15 \% \mathrm{SP}$ & $23.33 \pm 0.19^{a b}$ & $19.83 \pm 0.53^{\mathrm{de}}$ & $17.58 \pm 0.15^{\mathrm{e}}$ & $17.92 \pm 0.31^{\text {ef }}$ & $82.67 \pm 0.63^{e}$ \\
\hline $\mathrm{KP}+17.5 \% \mathrm{SP}$ & $23.17 \pm 0.17^{\text {abc }}$ & $19.33 \pm 0.38^{\text {ef }}$ & $17.00 \pm 0.28^{\mathrm{e}}$ & $16.67 \pm 0.26^{\mathrm{gh}}$ & $79.08 \pm 0.47^{f}$ \\
\hline $\mathrm{KP}+20 \% \mathrm{SP}$ & $20.75 \pm 0.59^{d}$ & $18.33 \pm 0.43^{f}$ & $16.17 \pm 0.21^{\mathrm{f}}$ & $15.75 \pm 0.22^{\mathrm{h}}$ & $75.67 \pm 0.38^{g}$ \\
\hline
\end{tabular}

In conclusion, results for kiwi fruits and cantaloupe nectar blends appear that the nectar blends containing equal percentage of $10 \%$ spirulina had the higher score in all attributes and most acceptable to panelists due to better consistency and flavor. This indicates that spirulina, which is higher in all chemical 
composition, protein and amino acids, essential fatty acids, vitamins, naturally colloidal minerals, phytopigments, could be blended with kiwi fruits and cantaloupe in the preparation of juices and nectars. The results are in agreement with McCarty (2007) and McCarty et al. (2010) they were found that the spirulina was improved the quality of fruits juice for their chemical composition, also are agreement with Akubor (2003) and Jurmkwan et al. (2008).

Table 8. Sensory properties of spirulina and cantaloupe nectar blends (mean \pm S.E.)

\begin{tabular}{|c|c|c|c|c|c|}
\hline \multirow[b]{2}{*}{$\begin{array}{l}\text { Products } \\
\text { (Nectar blends) }\end{array}$} & \multicolumn{5}{|c|}{ Sensory attributes } \\
\hline & $\begin{array}{c}\text { Texture } \\
\text { (mouthfeel) } \\
(25)\end{array}$ & $\begin{array}{l}\text { Color } \\
(25)\end{array}$ & $\begin{array}{l}\text { Taste } \\
(25)\end{array}$ & $\begin{array}{l}\text { Odor } \\
(25)\end{array}$ & $\begin{array}{c}\text { Overall } \\
\text { acceptability } \\
(\mathbf{1 0 0})\end{array}$ \\
\hline Cantaloupe nectar & $17.83 \pm 0.24^{\mathrm{g}}$ & $19.00 \pm 0.37^{\mathrm{f}}$ & $19.08 \pm 0.31^{d}$ & $18.67 \pm 0.43^{d}$ & $82.75 \pm 0.65^{\mathrm{e}}$ \\
\hline $\mathrm{CP}+2.5 \% \mathrm{SP}$ & $20.08 \pm 0.23^{f}$ & $20.42 \pm 0.31^{\mathrm{e}}$ & $20.42 \pm 0.36^{c}$ & $20.50 \pm 0.31^{c}$ & $86.25 \pm 0.46^{d}$ \\
\hline $\mathrm{CP}+5 \% \mathrm{SP}$ & $21.50 \pm 0.34^{\text {de }}$ & $21.42 \pm 0.29^{c d}$ & $21.75 \pm 0.35^{b}$ & $21.41 \pm 0.29^{b}$ & $89.92 \pm 0.48^{b c}$ \\
\hline $\mathrm{CP}+7.5 \% \mathrm{SP}$ & $22.25 \pm 0.33^{\text {cd }}$ & $22.17 \pm 0.27^{b c}$ & $22.83 \pm 0.32^{a}$ & $21.91 \pm 0.23^{b}$ & $92.33 \pm 0.67^{a}$ \\
\hline $\mathrm{CP}+10 \% \mathrm{SP}$ & $23.25 \pm 0.28^{b}$ & $22.83 \pm 0.24^{\text {ab }}$ & $22.75 \pm 0.30^{a}$ & $23.08 \pm 0.19^{a}$ & $91.25 \pm 1.20^{\mathrm{ab}}$ \\
\hline $\mathrm{CP}+12.5 \% \mathrm{SP}$ & $24.08 \pm 0.23^{a}$ & $23.25 \pm 0.25^{a}$ & $21.00 \pm 0.35^{b c}$ & $21.42 \pm 0.19^{b}$ & $88.75 \pm 0.49^{c}$ \\
\hline $\mathrm{CP}+15 \% \mathrm{SP}$ & $23.00 \pm 0.28^{b c}$ & $21.67 \pm 0.28^{c d}$ & $19.17 \pm 0.32^{d}$ & $19.91 \pm 0.29^{c}$ & $83.08 \pm 0.65^{\mathrm{e}}$ \\
\hline $\mathrm{CP}+17.5 \% \mathrm{SP}$ & $22.08 \pm 0.36^{d}$ & $21.08 \pm 0.19^{\text {de }}$ & $17.83 \pm 0.46^{\mathrm{e}}$ & $18.17 \pm 0.27^{d}$ & $79.00 \pm 1.19^{f}$ \\
\hline $\mathrm{CP}+20 \% \mathrm{SP}$ & $21.17 \pm 0.32^{\mathrm{e}}$ & $19.42 \pm 0.38^{f}$ & $16.50 \pm 0.26^{f}$ & $16.58 \pm 0.23^{e}$ & $74.00 \pm 0.58^{\mathrm{g}}$ \\
\hline
\end{tabular}

\section{Conclusion}

In conclusion, the present data indicated that cantaloupe and kiwi fruits nectars products are relatively higher in their nutritional values and all of these products are considered to be good sources of vit. $\mathrm{C}$ for adult man.

\section{References}

A.O.A.C. (2005) Official Methods of Analysis. Association of Official Analytical, Che-mists 18th ed., Washington, DC, USA.

Akubor P.I. (2003) Influence of storage on the physicochemical, microbiological and sensory properties of heat and chemically treated melonbanana beverage. Plant Foods for Human Nutrition 58(3) 1-10.

Branger B.; Cadudal J. L.; Delobel M.; Ouoba H.; Yameogo P.; Ouedraogo D.; Guerin D.; Valea A.; Zombre C. and Ancel P. (2003) personnels des CREN. Spirulina as a food supplement in case of infant malnutrition in Burkina-Faso. Archives de Pédiatrie, 10 ( 5) 424-431.

Cassano A.; Donato L. and Drioli E. (2007) Ultrafiltration of kiwifruit juice: Operating parameters, juice quality and membrane fouling. Journal of Food Engineering 79(2)613-621.

Connie L. Fisk; Mina R. Mcdaniel; Bernadine C. Strik and Yanyun Zhao (2006) Physicochemical, Sensory, and Nutritive Qualities of Hardy Kiwifruit (Actinidia arguta 'Ananasnaya') as Affected by Harvest Maturity and Storage. Journal of food science 71(3)204-210.

Desai Krutika and Sivakami Subramanian (2004) Spirulina The Wonder Food of the 21st Century. APBN 8 (23)1298-1302. www.asiabiotech.com Clinical Application, Source: www.biol.tsukuba.ac.jp/ inouge/ino/cy/ spirulina.gif.

Dolly, W.D. (2014) Biotechnological Potentials and Role of Cyanobacteria in Agriculture and Industry. Division of Microbiology Indian Agricultural Research Institute New Delhi-110012, India.

El-Mansy, H.A.; Sharoba, A.M.; Bahlol, H.El.M. and El-Desouky, A.I. (2005). Rheological properties of mango and papaya nectar blends. Ann. of Agric. Sc., Moshtohor, 43(2): 665-686.

Falquet J.(2012) The Nutritional Aspects of Spirulina, Antenna Technologies, http://antenna.ch/en/documents/AspectNut_UK.p df (accessed on 7/12/2012).

FAO (2004). Food and Agriculture Organization. Products Year Report Rome.

Fradique M.; Batista A.P.; Nunes M.C.; Gouveia L.; Bandarra N.M. and Raymundo A. (2010) Incorporation of Chlorella vulgaris and Spirulina maxima biomass in pasta products. Part 1: Preparation and evaluation. Journal of the Science of Food and Agriculture, 90: 1656-1664.

Habib M.A.B.; Parvin M.; Huntington T.C. and Hasan M.R. (2008) A Review on Culture, Production and Use of Spirulina as Food for Humans and Feeds for Domestic Animals and Fish, FAO Fisheries and Aquaculture Circular No. 1034.

Henrikson R. (2009) Earth Food Spirulina, Ronore Enterprises, Inc., Hana, Maui, Hawaii, USA.

http://www.researchpub.org/journal/ijfns/ijfns.html.

Jurmkwan Sangsuwana; Nithiya Rattanapanone and Pornchai Rachtanapun (2008) Effect of chitosan/methyl cellulose films on microbial and quality characteristics of fresh-cut cantaloupe and pineapple. Postharvest Biology and Technology 49(3) 403-410. 
Li Ding-Mei and Qi Yu-Zao (1997) Spirulina industry in China: Present status and future prospects. Journal of Applied Phycology 9 (1) 2528.

Liu Y.; Feng Y. and Lun J. (2012) Aqueous twophase countercurrent distribution for the separation of c-phycocyanin and allophycocyanin from Spirulina platensis. Food and Bioproducts Processing, 90: 111-117.

McCarty M.F. (2007) Clinical potential of Spirulina as a source of phycocyanobilin. Journal of Medicinal Food, 10 (4) 566-570.

McCarty M.F.; Barroso-Aranda J. And Contreras F. (2010) Potential complementarity of highflavanol cocoa powder and spirulina for health protection. Medical Hypotheses, 74: 370-373.

Nagata M. and Yamashita I. (1992) Simple method for simultaneous determination of chlorophyll and carotenoids in tomato fruit. Journal of Japanese Society of Food Science and Technology, 39, 925928.

Onweluzo J.C.; Vijayalakshmi M.R.; Vijayanand P. and Eipeson W.E. (1999) Detarium Microcarpum Polysaccharide as a Stabilizer in Processed Fruit Products. Lebensm.-Wiss. u.Technol., 32: 521- 526.

Osman M. Eman (2012) Using of fibers to produce of some special foods. M.Sc. Thesis, Fac. of Agric., Moshtohor, Benha Univ., Egypt.

Pearson D. (1976) The chemical analysis of food, $7^{\text {th }}$ edn. Churchill, London.

Pearson, D. (1976). The Chemical Analysis of Food 7th Ed. Churchill London U.D.
Peciukoniene M.; Stukas R. and KemeryteRiaubiene E. (2001) Peculiarites of nutrition and energy consumption in athletes. Sporto mokslas, 1(23):69-74.

Sharoba A.M. (1999). Rheological studies on some foods. M.Sc. Thesis, Fac. of Agric., Moshtohor, Zagazig Univ., Egypt.

Sharoba A.M.; Bahlol H.E.M. and El-Desouky A.I.(2007) Establishing a schedule to determine the optimal thermal process time for some canned fruit product. Annals of Agric. Sci. Mostohor, 45(1): 125-145.

Sharoba A.M.; El-Desouky A.I. and Mohamed M.H. (2012) Effect of addition some hydrocolloids and sweeteners on flow behavior and sensory properties of papaya-apricot nectar blends. Journal of Food Processing \& Technology, 3(8) $\quad 170 . \quad$ http://dx.doi.org/10.4172/21577110.1000170 .

Snedecor G.W. and Cochran W.G. (1989) Statitical methods. $8^{\text {th }}$ ed. Iowa State Univ. Press, Ames, Iowa.

Upasani C.D. and Balaraman R. (2003) Protective effect of Spirulina on lead induced deleterious changes in the lipid peroxidation and endogenous antioxidants in rats. Phytotherapy Research 17, 330-334.

Vijayarani, D.; Ponnalaghu, S. and Rajathivya, J. (2012) Development of Value Added Extruded Product Using Spirulina. International Journal of Health Sciences and Research 2 (4) 42-47. 


\section{استخدام طحلب الأسبيرولينا لتحسين القيمة الغذائية لبعض مخاليط نكتار الكيوى والكنتالوب}

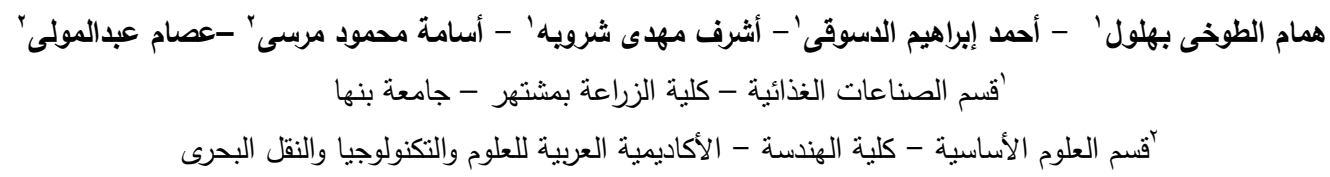

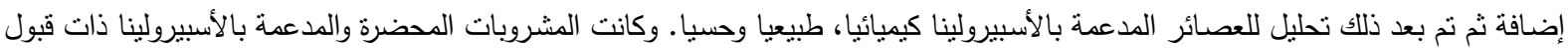

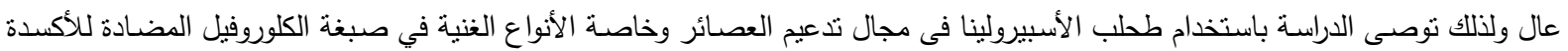
والمفيدة للصحة العامة منل الكيوى والكنتالوب .

الكلمات المساعدة: الأسبيرولينا - نكتار الكيوى - نكتار الكنتالوب - التركيب الكيماوي - القيمة التغذوية - الاختبارات الحسية - الاختبارات الطبيعية. 